\title{
KELAYAKAN REPLANTING KARET PADA KONDISI MUTU BOKAR DAN HARGA JUAL YANG RENDAH DI KABUPATEN MUARA ENIM SUMATERA SELATAN
}

\author{
Riswani, Yunita, Henny Malini dan Thirtawati \\ Jurusan Sosial Ekonomi Pertanian, Fakultas Pertanian Universitas Sriwijaya, Jl Raya Palembang- \\ Prabumulih km 32 Indralaya, Ogan Ilir, Sumatera Selatan, Indonesia \\ Email: riswani@fp.unsri.ac.id
}

Diterima 15 November 2019, disetujui 22 Mei 2020

\begin{abstract}
ABSTRAK
Fluktuasi harga karet yang sekarang terjadi dengan kecenderungan menurun, membuat petani karet di Sumatera Selatan mengalami dilema untuk melaksanakan replanting. Pada satu sisi tanaman karet yang mayoritas sudah berumur lebih dari 25 tahun sudah harus dilakukan replanting karena produktifitas semakin menurun, sementara jika tidak dilakukan maka petani dapat kehilangan mata pencaharian, karena usahatani karet merupakan mata pencaharian utama. Beranjak dari kondisi tersebut maka penelitian ini bertujuan untuk mendeskripsikan pengusahaan komoditi karet yang sekarang dilakukan petani pada kondisi menjelang replanting dan harga yang tergolong rendah yang berdampak pada mutu Bokarnya, serta menganalisis kelayakan komoditi karet dari aspek teknis, manajemen, pemasaran dan finansial untuk dilakukan replanting di tingkat petani pada kondisi pengusahaan yang sekarang dilakukan dan perkembangan harga yang sekarang berlaku. Penelitian dilakukan di Kabupaten Muara Enim sebagai salah satu wilayah sentra karet di Sumatera Selatan Dengan menggunakan metode survey, pengumpulan data primer dilakukan dengan metode wawancara pada 50 responden yang dipilih secara random. Pengolahan data dilakukan dengan metode analisa kualitatif, dan dilanjutkan dengan analisa kelayakan menggunakan kriteria kelayakan $\mathrm{B} / \mathrm{C}$ ratio, $\mathrm{R} / \mathrm{C}$ ratio, NPV, IRR, Payback ratio dan perhitungan BEP, yang dilanjutkan dengan analisis sensitifitas. Hasil analisa menunjukkan bahwa pengusahaan perkebunan karet dan pengolahan Bokar yang dilakukan petani belum mengikuti pengusahaan karet dan pengolahan Bokar yang dianjurkan dalam GAP karet, dan meskipun kondisi harga sekarang masih tergolong rendah, namun masih layak untuk diusahakan yang dibuktikan dengan semua nilai kriteria kelayakan usaha berada pada kriteria layak, sehingga replanting masih direkomendasikan untuk dilakukan pada tanaman karet yang sudah memasuki usia tidak produktif lagi

Kata kunci:_bokar, karet, kelayakan, replanting
\end{abstract}

\section{ABSTRACT}

The current rubber price fluctuation with downward trend, makes rubber farmers in South Sumatra experience a dilemma to carry out replanting. The majority of rubber plants that are more than 25 years old must be replanted because productivity decreases, if not done, farmers can lose their livelihoods because rubber farming is the main livelihood. This condition is the background of this study which aims to describe the rubber farming that is now being carried out by farmers in conditions approaching replanting and relatively low prices that have an impact on the quality of the Bokar, as well as analyzing the feasibility of rubber commodities from technical, management, marketing and financial aspects. The survey research was conducted in Muara Enim Regency as one of the rubber center areas in South Sumatra, primary data collection was conducted by interviewing 50 respondents who were randomly selected. Data processing was done by qualitative analysis methods, and followed by a feasibility analysis using the eligibility criteria of $B / C$ ratio, $R / C$ ratio, NPV, IRR, Payback ratio and BEP calculation, followed by sensitivity analysis. The result showed that the rubber plantation and Bokar 
processing undertaken by farmers has not followed the recommended rubber farming and Bokar processing, and although the current price conditions are still relatively low, it is still feasible to be undertaken as evidenced by all the values of the business feasibility criteria being in the feasible criteria, so replanting is still recommended for rubber plants that are no longer productive

Keywords: feasibility, replanting, rubber, slab

\section{PENDAHULUAN}

Kabupaten Muara Enim sebagai satu dari wilayah produsen karet utama di Provinsi Sumatera Selatan saat ini para petaninya mengalami dilema terkait rencana pelaksanaan replanting kebun karetnya yang mayoritas sudah mulai memasuki usia tidak produktif lagi (rerata di atas 25 tahun). Menurut Balai Penelitian Sembawa (2010) bahwa, tanaman karet dapat diusahakan selama kurang lebih 30 tahun dengan rincian masa TBM (tanam belum menghasilkan) sekitar 5 tahun dan masa TM (tanaman menghasilkan) sekitar 25 tahun. Artinya, dengan umur tanam yang sekarang, petani sudah harus memikirkan untuk melaksanakan replanting. Namun disisi lain, harga jual Bokar tidak kunjung membaik, serta mutu Bokar pun semakin tidak dapat diperbaiki karena dengan harga jual yang rendah, maka pendapatan yang diperolehpun berkorelasi positif, akibatnya pengeluaran untuk pembelian input produksi dan pemeliharaan juga dibatasi. Disisi lain, jika petani tidak segera melakukan replanting, maka beberapa tahun mendatang petani akan kehilangan sumber mata pencaharian mereka, sementara itu saat ini produktifitaspun akan semakin menurun. Menurut Nurhakim dan Yusnu (2014), faktor penyebab yang membuat produktifitas karet hampir di seluruh wilayah di Indonesia masih rendah yaitu : (1) umur tanaman karet sudah tua, (2) pemeliharaan berupa pembersihan dan pemupukan tidak sesuai anjuran, (3) belum digunakannya klon unggul, dan (4) penyadapan tidak sesuai aturan.

Pada beberapa wilayah pengusahaan karet di Kabupaten Muara Enim saat ini berada pada kondisi penyebab produktifitas menurun tersebut. Kondisi tersebut cenderung semakin banyak terjadi dikarenakan harga karet yang tak kunjung membaik, membuat motivasi petani menurun untuk memperbaiki cara berusahatani karet yang benar, serta menghasilkan Bokar yang bermutu baik, karena harga yang mereka terima juga tidak jauh berbeda. Beberapa kondisi yang terjadi tersebut menjadi latar belakang utama penelitian ini dilakukan agar dapat berkontribusi memberikan alternatif solusi dalam pengambilan keputusan petani untuk melanjutkan usahatani karet atau mengubah ke komoditi lain yang lebih menguntungkan. Hasil analisis diperlukan juga penggambaran terhadap pola pengusahaan karet yang sekarang dilakukan petani, sehingga dapat diberikan solusi perbaikan jika ingin melakukan replanting agar tidak ada lagi alasan pedagang memberikan harga murah dengan alasan Bokar yang dihasilkan petani bermutu rendah, sehingga tidak mampu bersaing di pasar.

Berdasarkan kondisi tersebut, maka permasalahan yang menarik untuk dicarikan solusinya pada penelitian ini adalah; (1) bagaimana pengusahaan perkebunan karet dan pengolahan Bokar yang dilakukan petani pada masa menjelang replanting dan kecenderungan harga jual yang belum membaik, dan (2) apakah replanting karet pada kondisi harga karet dan mutu Bokar yang masih tergolong rendah masih layak secara finansial untuk dilakukan. Dengan demikian, maka secara spesifik penelitian ini bertujuan untuk mendeskripsikan pengusahaan komoditi karet yang sekarang dilakukan petani pada kondisi menjelang replanting dan harga yang tergolong rendah yang berdampak pada mutu Bokarnya, serta menganalisis kelayakan komoditi karet dari aspek teknis, pemasaran dan finansial untuk dilakukan replanting di tingkat petani pada kondisi pengusahaan yang sekarang dilakukan dan perkembangan harga yang 
sekarang berlaku. Adapun hipotesis yang diduga untuk diuji dalam penelitian ini adalah usahatani karet pada masa sekarang masih layak untuk diusahakan sehingga masih dapat dilakukan replanting untuk pengusahaan dalam rentang umur produktifnya.

\section{METODE PENELITIAN}

Penelitian ini dilakukan di Kabupaten Muara Enim sebagai salah satu wilayah produsen utama karet di Sumatera Selatan yang sebagian besar komoditi karet yang diusahakan petani sudah berada pada kondisi menjelang replanting (rerata usia kebun $>25$ tahun), dengan cara pengusahaan kebun dan pengolahan Bokar tergolong bervariasi, sehingga diasumsikan mampu mewakili pola pengusahaan karet dan pengolahan Bokar di Sumatera Selatan, yang memang mayoritas diusahakan oleh rakyat (perkebunan rakyat), secara purposive dipilih Kecamatan Rambang Dangku dengan pertimbangan mayoritas pengusahaan karet petani disini, memenuhi kriteria yang diinginkan.

Metode survey dipilih sebagai metode yang digunakan dalam penelitian ini, dengan pengumpulan data primer dilakukan melalui wawancara responden yang dipilih secara random sebanyak 50 responden dari 190 anggota target populasi (petani yang mengusahakan karet dengan umur tanam $>25$ tahun dan segera akan melakukan replanting). Data sekunder yang relevan yang digunakan sebagai data pendukung dalam pembahasan diperoleh melalui OPD-OPD terkait seperti BPS dan Dinas Perkebunan di tingkat kabupaten dan provinsi serta dokumen hasilhasil penelitian terkait, serta data-data yang dipublish oleh lembaga yang kompeten.

Data-data yang diperoleh, selanjutnya ditabulasi berkelompok dan terstruktur untuk digunakan dalam analisis data untuk menguji hipotesis dan menjawab tujuan yang ingin dicapai. Analisa deskriptif digunakan untuk mendeskripsikan gambaran pola pengusahaan kebun karet dan pengolahan Bokar yang dilakukan petani dengan mengkomparasi prosesnya dengan Good Agricultural
Practises (GAP) karet dianjurkan untuk dilakukan. Perhitungan analisa kelayakan menggunakan beberapa kriteria dalam penentuan kelayakan suatu proyek, meliputi Net Present Value (NPV), Internal Rate of Return (IRR), B/C Ratio, Payback Period (PBP), Break Event Point (BEP).

Selanjutnya, analisis kualitatif dilakukan dengan menganalisis aspek pasar, aspek teknis, aspek manajemen dan hukum, aspek sosial, ekonomi, dan budaya serta aspek lingkungan. Analisis kualitatif dilakukan untuk mengetahui apakah pengembangan usahatani kelapa sawit dan karet dalam upaya re-planting ini menguntungkan dari segi non finansialnya.

\section{HASIL DAN PEMBAHASAN}

\section{Pengusahaan Komoditi Karet yang Sekarang Dilakukan Petani Pada Kondisi Menjelang Replanting dan Harga yang Tergolong Rendah}

Bentuk pengusahaan yang dideskripsikan pada bagian ini adalah bagian dari budidaya tanaman karet yang dilakukan petani saat menjelang replanting dan harga yang tergolong rendah. Kondisi menjelang replanting ditandai dengan usia rata-rata tanaman karet telah melewati usia produktif (>25 tahun), sedangkan kondisi harga yang tergolong rendah dideteksi dari trend perkembangan harga karet dalam 5 tahun terakhir yang dirilis Dinas Perkebunan Provinsi Sumatera Selatan dan hasil pengumpulan data primer yang menunjukkan harga karet pada kurun waktu tahun 20142018 berada pada harga secara berurut tahun yaitu Rp.13.000/Kg di tahun 2012 dan 2013, menurun menjadi Rp. $8.000 / \mathrm{Kg}$ di tahun 2014, hingga di tahun 2018, di saat penelitian ini dilakukan masih berada di harga Rp.7.000 - Rp.8.000 per Kg, belum kembali ke masa normalnya harga karet sebelum tahun 2013, yaitu di angka Rp.12.000 - Rp. 14.000,- per $\mathrm{Kg}$.

Pada tanaman karet di lokasi penelitian, sistem budidaya yang dilakukan saat ini meliputi kegiatan pemeliharaan dan 
pemanenan. Tindakan pemeliharaan karet adalah penyiangan gulma, pemupukan, pengendalian hama dan penyakit, dan pemeliharaan pada masa panen. Pada kegiatan pemeliharaan, saat ini yang paling banyak dilakukan petani hanya kegiatan penyiangan gulma, yang mayoritas dilakukan secara kimiawi dan manual. Penyiangan gulma secara manual menggunakan alat pemotong rumput ataupun menggunakan sengkuit, yang umumnya juga tidak rutin dilakukan, hanya jika kondisi lahan di sekitar tanaman sudah banyak ditumbuhi gulma, yang umumnya dilakukan rata-rata 1 bulan satu kali. Penyiangan secara kimiawi pada tanaman karet, biasanya dilakukan rata-rata 1 tahun 3 kali sesuai dengan kondisi lahan, penyemprotan dengan menggunakan sprayer besar. Produk yang digunakan adalah round up, dengan dosis $20 \mathrm{ml}$ atau 1 botol / ha dengan jumlah air yang disesuaikan.

Pada tanaman karet yang sudah tua ini mayoritas petani di daerah penelitian masih menganggap dengan pemberian pupuk yang banyak bisa mempertahankan tingkat produktivitas karet. Proses pemberian pupuk pada tanaman karet rata-rata dilakukan 3 kali dalam satu tahun, dengan produk pupuk subsidi dari pemerintahan yang didapatkan dari koperasi desa dengan harga Rp 140.000 / karung yang berisi $50 \mathrm{~kg}$ yang mengandung Urea, Sp36, dan KCL. Dosis yang digunakan ialah $0,6 \mathrm{~kg} \mathrm{/} \mathrm{batang.} \mathrm{Pemberian} \mathrm{pupuk}$ tergantung dari keuangan dari petani jika keuangan sedang baik mereka akan melakukan pemupukan selama 3 kali dalam satu tahun dan ditambakan pupuk matahari yang harganya sekitar Rp 300.000 / karung 50 kg. Tetapi jika keuangan sedang memburuk maka pemupukan hanya dilakukan sebanyak 2 kali. Dosis yang digunakan ialah $0,5 \mathrm{Kg} /$ batang pohon. Pengaplikasian pupuk dilakukan oleh petani dengan cara menaburkan pupuk ke sekitar batang karet, ini dilakukan karena petani malas untuk melakukan penggalian untuk pemberian pupuk secara optimal ke batang mengingat tanaman sudah tua. Jika dibandingkan dengan GAP karet yang dikeluarkan Balai
Penelitian Karet Sembawa (2010), pemupukan tanaman karet sebaiknya tidak dilakukan pada pertengahan musim hujan karena pupuk mudah tercuci air hujan. Idealnya, pemupukan dilakukan pada pergantian musim hujan ke musim kemarau dengan cara digali di sekitar pohon. Sementara itu, kebutuhan jenis pupuk yang diberikan di antaranya pupuk urea, DS, dan $\mathrm{KCl}$ yang mudah diperoleh di pasaran. Dari hasil penelitian Anwar dan Suwarto (2016) menunjukkan bahwa pada karet yang umurnya sudah melewati masa produktif, penggunaan input seperti pupuk cenderung tidak mampu meningkatkan produktifitas kebun lagi, replanting adalah pilihan terbaik untuk dilakukan

Pengendalian hama dan penyakit pada daerah penelitian termasuk jarang dilakukan petani, dikarenakan kebun karet desa tersebut jarang terkena penyakit ataupun hama yang dapat mengancam kematian pada tanaman karet. Hama yang biasanya menyerang karet adalah ulat. Pengendalian terhadap hama ulat ialah menggunakan perstisida decis dicampurkan dengan solar. Dosis yang digunakan ialah $20 \mathrm{ml}$ decis dengan 1 liter solar untuk per ha lahan petani. Frekuensi penyemprotan yaitu sekitar $1-2$ kali dalam satu tahun melihat kondisi dari lahan ini tersendiri.

Pada bagian pemanen, petani karet melakukan pemanenan (penyadapan) setiap hari dan mengangkut hasilnya dalam satu hari. Dalam proses pemanenan dibagi menjadi beberapa petakan wilayah agar memudahkan petani dalam menentukan daerah yang belum tersadap dan yang sudah dilakukan penyadapan. Penyadapan setiap hari ini dilakukan oleh petani karena mata pencaharian mereka dari hasil karet, dan untuk mendapatkan hasilnya petani harus rajin melakukan penyadapan untuk mendapatkan lateks jika tidak ada proses penyadapan maka petani tidak bisa mendapatkan hasil dari penjualan lateks 
Tabel 1. Analisis Perbandingan Produksi Bokar Petani dengan Produksi Bokar Menurut Standar Nasional Indonesia Bokar (SNI No.06-2047-2002)

\begin{tabular}{|c|c|c|c|}
\hline No. & Uraian & SNI Bokar & Bokar Petani \\
\hline 1. & Bahan Pembeku & Asam Semut & Cuka Para \\
\hline 2. & Kebersihan Bokar & Tidak mengandung kontamin & $\begin{array}{l}\text { Kurang bersih dan } \\
\text { terkontaminasi }\end{array}$ \\
\hline 3. & Ukuran Bokar & Dicetak dalam ukuran tertentu & $60 \times 50 \times 40 \mathrm{~cm}$ \\
\hline 4. & $\begin{array}{l}\text { Kadar Karet Kering } \\
\text { (K3) }\end{array}$ & $50 \%$ di Tingkat Petani & $<50 \%$ \\
\hline
\end{tabular}

\section{Mutu Bokar dan Proses Pengolahannya}

Karet di wilayah kajian dijual dalam bentuk slab tebal dan lump mangkuk dengan cetakan kotak pembeku rata-rata $60 \times 50 \times 40$ $\mathrm{cm}$. Adapun proses pengolahan berikut bahan yang digunakan, yang dikomparasi dengn SNI, akan terlihat perbedaannya brikut ini (Tabel 1).

\section{Analisa Kelayakan Pengusahaan Karet untuk Pelaksanaan Replanting Karet}

Analisis kelayakan karet untuk keperluan replanting ini dilakukan dari sisi finansial dan non finansial. Analisis finansial bertujuan untuk mengetahui kelayakan usaha peremajaan dan karet melalui kriteria-kriteria aspek finansial. Analisis non finansial akan melihat usahatani karet kemudian akan dikaji untuk mengetahui kelayakan usahatani ini terhadap aspek-aspek finansial seperti aspek pasar, aspek teknis, aspek manajemen dan hukum, serta aspek lingkungan.

\section{Analisis Kelayakan Non Finansial Karet 1) Aspek Pasar}

Pada perkebunan karet rakyat, hasil pemanenan harus diolah kembali menjadi slab atau getah karet yang sudah mengalami pembekuan. Proses penjualan karet dilakukan rata-rata 2- 4 kali dalam sebulan tergantung jumlah dari kuantitas getah yang dihasilkan oleh petani. Untuk slab dilakukan penjualan kepada tengkulak ataupun koperasi. Jika hasil panen sedang tinggi maka petani akan langsung menjual karet kepada tengkulak, jika hasil panen sedang rendah petani lebih memilih melakukan penjualan bersama dengan hasil dari pihak koperasi. Untuk harga penjualan langsung kepada tengkulak Rp $8.000,00$ / kg, sedangkan jika melakukan penjualan bersama dengan pihak koperasi akan dikenakan biaya $\mathrm{Rp} 500$ - Rp 1.000 / kg. Untuk hasil produksi karet tidak susah untuk melakukan penjualan karena disana terdapat banyak tengkulak yang siap untuk menampung hasil produksi karet. Saluran pemasaran yang digunakan adalah sebagai berikut :

\section{2) Aspek Teknis}

Lokasi perkebunan rakyat yang dianalisis terletak di Kecamatan Rambang Dangku, Kabupaten Muara Enim ini mayoritas dimiliki oleh petani secara turun temurun ataupun membeli lahan disana. Luasan produksi kebun karet rakyat tergolong bervariasi dari 2 $\mathrm{Ha}-8 \mathrm{Ha}$, dengan rata-rata luas lahan 3,9 Ha, sehingga memberikan skala usaha yang layak untuk diusahakan

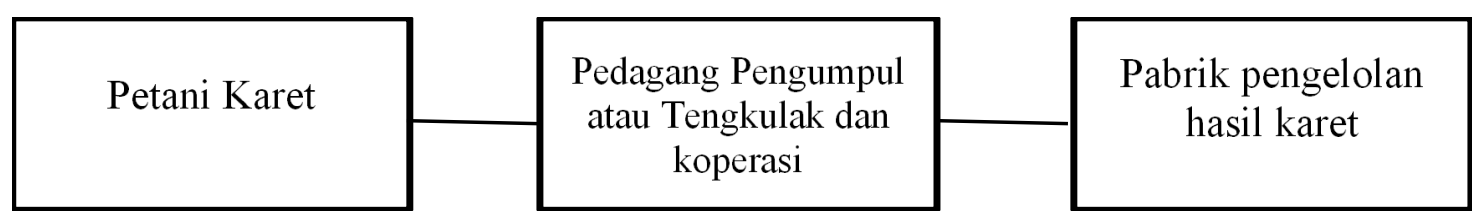

Gambar 1. Saluran Pemasaran Karet Petani 
Tabel 2. Kelayakan Usahatani Karet Berdasarkan Aspek Pasar

\begin{tabular}{cll}
\hline No & \multicolumn{1}{c}{ Indikator } & \multicolumn{1}{c}{ Keterangan } \\
\hline 1 & Produk & Getah karet/Slab \\
2 & Saluran Pemasaran & Petani Ke tengkulak atau koperasi \\
3 & Promosi & Tidak ada \\
4 & Harga & Ditentukan oleh tengkulak \\
\hline
\end{tabular}

Sarana produksi yang dimiliki petani dalam mengusahakan perkebunan karet tergolong masih sederhana namun masin bisa membantu pelaksanaan kegiatan budidaya. Peralatan yang digunakan antara lain cangkul, parang, semprotan, sadapan/pahat, talang sadapan, ember, dan bak pembeku. Sedangkan saseperti pupuk dan pestisida diperoleh petani dari toko-toko produksi pertanian atau pun koperasi yang berada di sekitar kecamatan. Bila mengalami kesulitan keuangan tidak mampu untuk membeli sarana produksi seperti pupuk atau obat-obatan, petani dapat meminta kepada koperasi untuk melakukan penyediaan bahan baku dan akan dibayarkan pada saat panen, ataupun petani biasannya melakukan peminjamaan dibank.

Sistem budidaya yang diterapkan petani dalam menjalankan proses produksi pada usahatani karet, umumnya hanya mengandalkan pengalaman selama bertani atau dipelajari secara otodidak dan dari

pengetahuan yang diperoleh secara turunmenurun. Pada kegiatan pemupukan, dilakukan rata-rata sebanyak 3 kali dalam kurun waktu 1 tahun dan jika keungan mereka sedang memburuk maka mereka akan melakukan pemupukan hanya 2 kali dalam kurun waktu 1 tahun. Dosis dalam setiap kali melakukan pemupukan dengan dosis yang sama tetapi hanya berbeda intensitasnya, tujuannya yaitu untuk tetap menjaga produktivitas karet saat memasuki umur yang sudah tidak produktif, dosis yang diberikan yaitu sebanyak 2 karung urea yang berjumlah $50 \mathrm{~kg} /$ karung, dan 1 karung KCL yang berjumlah $50 \mathrm{~kg} / 1$ karung diberikan kepada per 300 batang / ha. Pupuk yang biasanya diberikan oleh petani ialah pupuk dari PT Pusri yang bisa didapatkan pada koperasi desa dengan harga Rp 140.000 / karung.

Hama yang menyerang perkebunan karet meskipun jarang terjadi, umumnya adalah ulat. Dalam pengendalian hama ulat ini

Tabel 3. Kelayakan Usahatani Karet Berdasarkan Aspek Teknis

\begin{tabular}{|c|c|c|}
\hline No. & Indikator & Keterangan \\
\hline 1. & Lokasi Lahan & Lahan turun temurun atau membeli lahan \\
\hline 2. & Luas Lahan & 2 hektar sampai 8 hektar \\
\hline 3. & $\begin{array}{l}\text { Fasilitas Produksi dan } \\
\text { Pendukung }\end{array}$ & $\begin{array}{l}\text { FailitasPengunaan alat usahatani seperti cangkul, } \\
\text { parang, semprotan, sadapan/pahat, talang } \\
\text { sadapan, ember, dan bak pembeku. }\end{array}$ \\
\hline 4. & Ketersediaan Sarana Produksi & Toko pertanian sekitar desa dan koperasi desa \\
\hline 5. & Proses Produksi & $\begin{array}{l}\text { Pengalaman selama berusahatani atau } \\
\text { otodidak }\end{array}$ \\
\hline 6. & Pemupukan & $\begin{array}{l}\text { Dilakukan setahun } 2 \text { kali dengan pupuk } \\
\text { UREA dan KCL. }\end{array}$ \\
\hline 7. & Pengendalian Hama dan Penyakit & Penggunaan pestisida berupa Decis \\
\hline 8. & Pemeliharaan & $\begin{array}{l}\text { Penyiangan Dilakukan Secara Kimiawi } \\
\text { dengan menggunakan Roundup dengan } \\
\text { intensitas pemberian sebanyak } 1 \text { tahun } 3 \text { kali }\end{array}$ \\
\hline 9. & Panen & $\begin{array}{l}\text { Sebanyak } 365 \text { hari dengan sistem pembagian } \\
4 \text { hari panen } 1 \text { hari pengangkutan }\end{array}$ \\
\hline
\end{tabular}


Tabel 4. Kelayakan Usahatani Karet Berdasarkan Aspek Manajemen dan Hukum

\begin{tabular}{cll}
\hline No & \multicolumn{1}{c}{ Indikator } & \multicolumn{1}{c}{ Keterangan } \\
\hline 1 & Struktur organisasi & Tidak Ada pemilik lahan bertugas sebagai \\
& & mandor dan juga pegawai \\
2 & Sumber modal & Pribadi \\
3 & Izin yang perlukan & Tidak ada karena lahan yang diusahakan \\
& & kurang dari 25 hektar \\
\hline
\end{tabular}

biasannya digunakan pestisida berupa decis. Untuk pengaplikasiannya decis dan solat dicampurkan dengan perbandingan 1 decis : 2 solar lalu daun dan pohon yang terserang akan disemprotkan menggunakan sprayer besar. Sedangkan untuk membersihkan gulma biasanya dilakukan secara manual, namun ada juga yang dilakukan secara kimiawi dengan menggunakan herbisida.

Pada proses pemanenan (penyadapan), rata-rata petani karet memanfaatkan tenaga kerja dari dalam keluarga yaitu berupa petani itu sendiri dibantu dengan tenaga kerja dari dalam keluarga termasuk juga proses pengumpulan hasil dibantu oleh tenaga kerja dalam keluarga. Pemanenan dilakukan setiap hari dengan pembagian petakan wilayah, agar mempermudah proses penyadapan dan juga pengumpulan hasil rata-rata petani membagi waktu pemanenan dan waktu pengangkutan dengan hari 4 hari pemanenan dan 1 hari pengumpulan hasilnya.

Dari hasil deskripsi tersebut menunjukkan bahwa dari aspek teknis, meskipun mayoritas masih dengan pola sederhana, namun masih dapat dikatakan layak, karena petani dapat menjalankan usahataninnya dengan baik dan tidak mengalami kendala tertentu dari segi teknis.

\section{3) Aspek Manajemen dan Hukum}

Dalam manajerial pada perkebunan karet di wilayah kajian, tidak ada struktur organisasi secara formal. Biasanya pemilik kebun berperan sebagai pekerja itu sendiri dibantu dengan tenaga kerja dari dalam keluarga, karena pemeliharaan dan pemanenan karet dilakukan setiap hari jadi petani lebih memilih untuk mengurusi lahannya sendiri dikarenakan untuk menghemat biaya pengeluaran. Dengan harga karet yang fluktuatif seperti saat ini petani lebih memilih untuk mengurusi lahannya sendiri. Untuk pemanenan karet tidak terlalu berat, hanya saja proses yang cukup berat adalah pengumpulan hasil panen.

Sumber modal dalam menjalankan usahataninya berasal dari dana pribadi, bank dan juga koperasi. Dalam menjalankan usahannya, petani tidak perlu mengurus perizinan karena didasari Peraturan Kementerian Pertanian No. 26/permentan/OT.140/2/2007. Berdasarkan peraturan tersebut dapat diketahui bahwa usaha perkebunan dengan luas lahan kurang dari 25 ha tidak memerlukan izin berupa izin usaha perkebunan (IUP)

\section{4) Aspek Sosial, Ekonomi, dan Budaya \\ Keberadaan perkebunan karet membawa dampak yang positif bagi masyarakat di}

Tabel 5. Kelayakan Usahatani Karet Berdasarkan Aspek Sosial Budaya dan Ekonomi

\begin{tabular}{|c|c|c|}
\hline No & Indikator & Keterangan \\
\hline 1 & Peningkatan Ekonomi & $\begin{array}{l}\text { Peningkatan ada dilihat dari rumah yang sudah } \\
\text { pondasi batu bata dan kendaraan pribadi }\end{array}$ \\
\hline 2 & Penyerapan Tenaga Kerja & $\begin{array}{l}\text { Tidak ada dikarenakan untuk perkebunan karet } \\
\text { banyak menyerap tenaga kerja dari dalam } \\
\text { keluarga }\end{array}$ \\
\hline 3 & Pemanfaatan Lain Kelapa Sawit & Tidak ada. \\
\hline
\end{tabular}


Tabel 6. Kelayakan Usahatani Karet Berdasarkan Aspek Lingkungan

\begin{tabular}{clll}
\hline No & \multicolumn{1}{c}{ Indikator } & Keterangan \\
\hline 1. & Penggunaan pestisida & 1 tahun 3 kali & \\
.2 & Pencegahan polusi & Tidak ada & \\
\hline
\end{tabular}

Kecamatan Rambang Dangku, Kabupaten Muara Enim ini. Perkebunan karet tidak terlalu banyak menyerap tenaga kerja untuk proses pemeliharaan, hingga proses pemanenan, dalam proses budidaya karet ini dikarenakan tenaga kerja yang terserap banyak berada pada dalam keluarga itu sendiri. Dari dampak yang lainnya masyarakat disana ada beberapa yang membangun warung sederhana untuk tempet beristirahat maupun berkumpul setelah melakukan kerja dilahan mereka, dengan adanya perkebunan karet perekonomian masyarakat di wilayah inipun meningkat.

\section{Analisis Kelayakan Finansial Karet}

Analisis aspek finansial pada penelitian ini bertujuan untuk mengetahui kelayakan usaha perkebunan karet pada kegiatan usaha peremajaan yang akan dilakukan, pada kondisi perkembangan karet yang cenderung belum stabil. Menurut Syarifah (2014), analisa kelayakan pada usaha perkebunan karet di Sumatera Selatan dengan kondisi normal maupun pada harga yang menurun masih tetap layak untuk diusahakan. Pada analisis kelayakan finansial karet, dilakukan pula analisis switching value yakni analisis yang digunakan untuk melihat seberapa jauh elastisitas kelayakan usaha terhadap perubahan salah satu komponen yang paling berpengaruh dalam usaha. Komponen yang digunakan dalam perhitungan analisis switching value pada usaha ini adalah pupuk dan hasil produksi dari karet. Hal tersebut dikarenakan pupuk merupakan biaya variabel terbesar dalam pelaksanaan usaha karet, dan juga hasil produksi merupakan penerimaan terbesar dalam pelaksanaan usahatani karet pada wilayah ini.

\section{1) Asumsi Dasar}

Analisis kelayakan finansial usahatani karet sebagai bahan pertimbangan untuk pelaksanaan replanting ini menggunakan beberapa asumsi sebagai berikut :

1. Analisis usaha perkebunan karet merupakan analisis perkebunan skala rakyat yakni 2 ha.

2. Perhitungan umur usaha dimulai pada umur ke 0 pada dimulainya peremajaan sampai dengan umur ke 25 dengan menghitung batas usia produktif tanaman karet.

3. Tingkat suku bunga yang digunakan adalah tingkat suku bunga kredit usaha rakyat Bank Sumsel Babel dengan tingkat suku bunga 7 persen.

4. Biaya yang dikeluarkan untuk usahatani karet terdiri dari biaya investasi, biaya peremajaan, dan biaya operasional TBM dan TM.

5. Biaya investasi yang dikeluarkan pada tahun ke 0 dan biaya reinvestasi dikeluarkan untuk peralatan yang telah habis masa umur ekonomisnnya

6. Biaya peremajaan yang dikeluarkan petani pada tahun ke 0 untuk upah tenaga kerja dan sarana produksi dalam melakukan peremajaan karet yang sudah tidak produktif lagi.

7. Biaya operasional terdiri dari biaya yang menunjang operasional usahatani karet, yang terbagi menjadi 2 yaitu biaya operasional tanaman belum menghasilkan (TBM) tahun ke 1 sampai tahun ke 3 dan biaya operasional tanaman menghasilkan (TM) tahun ke 4 sampai tahun ke 5 dan diasumsikan biaya dari fase TBM dan TM itu konstan selama umur masa proyek.

8. Penentuan harga jual yang digunakan harga yang berlaku pada saat penelitian dilakukan dan diasumsikan konstan 
hingga umur usaha berakhir, yaitu sebesar Rp 8.000,00 / kg.

9. Produksi karet memiliki potensi kenaikan produksi lateks selama umur produktifnya dari $20 \%$ sampai $32 \%$ pada puncak masa puncak umur produktif tanaman.

10. Tingkat produktifitas tanaman karet diasumsikan pada bulan Februari, Maret, dan April mengalami kenaikan produksi sebanyak $12 \%$ dikarenakan tingkat curah hujan yang paling rendah berdasarkan data BPS tahun 2018 dan mengalami penurunan produksi sebanyak 50\% dikarenakan tingkat curah hujan paling rendah berdasarkan data BPS tahun 2018.

11. Dalam penelitian ini analisis sensitifitas diasumsikan terhadap penurunan harga lateks sebesar 5\% untuk melihat apakah penurunan harga lateks sensitif terhadap penelitian ini.

\section{2) Biaya Investasi}

Biaya investasi yang dikeluarkan dalam pelaksanaan usaha peremajaan perkebunan karet oleh petani dalam penelitian ini adalah pembelian alat sadap, parang, dan cangkul, sprayer besar, gunting stek, talang sadap, mangkok sadap, dan bak pembeku. Total biaya yang dikleurakan untuk investasi peralatan ini adalah sebesar Rp 12.994.600,-

\section{3) Biaya Pembukaan Lahan}

Pada kegiatan pembukaan lahan yang terdiri dari kegiatan persiapan lahan, penebangan, penebasan, dan pembersihan, pemancangan tanam, pengaplikasian pupuk, pengendalian OPT, dan penanaman dan pelubangan, memerlukan total biaya sebesar Rp 13.710.000,- untuk pembayaran upah tenaga kerjanya, dengan rincian pada Tabel 7.

Pada kegiatan pembukaan lahan dan penanaman ini biaya sarana produksi meliputi pembelian bibit, ajir, pupuk dan herbisida. Bibit yang dibutuhkan yaitu sebanyak 1.100 bibit, dengan 1.000 bibit untuk ditanam dan 100 bibit untuk dilakukan penyulaman. Biaya pembelian bibit sebesar Rp 11.990.000, dan pembelian bahan sarana produksi lainnya sebesar Rp 7.373.000

Pada usaha peremajaan perkebunan karet pada tanaman yang tidak produktif lagi, petani melakukan penumbangan tanaman dengan gergaji mesin dan kampak bertujuan agar tidak merusak batang pohon. Batang karet memiliki nilai ekonomis yang biasanya diekspor ke Malaysia ataupun dijual di Indonesia. Selanjutnya biaya tenaga kerja lainnya berupa pemancangan, penanaman,

Tabel 7. Biaya Tenaga Kerja Pembukaan Lahan

\begin{tabular}{|c|c|c|c|c|c|c|c|}
\hline No. & Struktur Biaya & Volume & Satuan & $\begin{array}{c}\text { Harga } \\
\text { (Rp/satuan) }\end{array}$ & $\begin{array}{c}\text { Biaya } \\
\text { total (Rp) }\end{array}$ & $\begin{array}{l}\text { Luas } \\
\text { Lahan }\end{array}$ & $\begin{array}{l}\text { Total biaya } \\
\text { (Rp) }\end{array}$ \\
\hline 1. & $\begin{array}{l}\text { Persiapan lahan } \\
\text { (Penebangan,pe } \\
\text { nebasan \& } \\
\text { pembersihan) }\end{array}$ & 1 & Paket & 9.000 .000 & 9.000 .000 & 2 & 9.000 .000 \\
\hline 2. & Pemancangan & 500 & Batang & 3.000 & 1.500 .000 & 2 & 3.000 .000 \\
\hline 3. & $\begin{array}{l}\text { Pengaplikasian } \\
\text { pupuk dasar }\end{array}$ & 2 & HK & 60.000 & 120.000 & 2 & 240.000 \\
\hline 4. & $\begin{array}{l}\text { Pengendalian } \\
\text { OPT }\end{array}$ & 1 & HK & 60.000 & 60.000 & 2 & 120.000 \\
\hline 5. & $\begin{array}{l}\text { Pemeliharaan } \\
\text { teras, saluran } \\
\text { drainase }\end{array}$ & 5 & HK & 75.000 & 375.000 & 2 & 750.000 \\
\hline 6. & Penanaman & 5 & $\mathrm{HK}$ & 60.000 & 300.000 & 2 & 600.000 \\
\hline & Total & & & & 11.355 .000 & & 13.710 .000 \\
\hline
\end{tabular}


Tabel 8. Biaya Sarana Produksi Peremajaan Karet

\begin{tabular}{llrrrrrr}
\hline No & Struktur Biaya & Volume & Satuan & $\begin{array}{c}\text { Biaya/ } \\
\text { satuan } \\
(\mathrm{Rp})\end{array}$ & $\begin{array}{c}\text { Biaya total } \\
(\mathrm{Rp})\end{array}$ & $\begin{array}{c}\text { Frekuensi } \\
\text { Lahan }\end{array}$ \\
\hline 1 & Benih karet siap tanam & 550 & Batang & 10.900 & 5.995 .000 & 1 & 2 \\
2 & Ajir & 500 & Batang & 1.000 & 500.000 & 1 & 2 \\
3 & Pupuk Dasar Urea & 60 & $\mathrm{Kg}$ & 5.250 & 315.000 & 4 & 2 \\
4 & Pupuk Dasar Sp36 & 35 & $\mathrm{Kg}$ & 5.875 & 205.625 & 4 & 2 \\
5 & Pupuk Dasar KCL & 20 & $\mathrm{Kg}$ & 9.000 & 180.000 & 4 & 2 \\
7 & Herbisida & 2 & $\mathrm{~L} / \mathrm{Kg}$ & 90.000 & 180.000 & 1 & 2 \\
8 & Fungisida & 2 & $\mathrm{~L} / \mathrm{Kg}$ & 102.000 & 204.000 & 1 & 2 \\
\hline & Total & & & & 7.579 .625 & & \\
\hline
\end{tabular}

pengendalian OPT, pemupukan dasar dengan jumlah biaya $\mathrm{Rp}$ 13.710.000. Secara keseluruhan, total biaya investasi usaha peremajaan karet ialah Rp 34.250.000,-.

Pada usaha peremajaan perkebunan karet pada tanaman yang tidak produktif lagi, petani melakukan penumbangan tanaman dengan gergaji mesin dan kampak bertujuan agar tidak merusak batang pohon. Batang karet memiliki nilai ekonomis yang biasanya diekspor ke Malaysia ataupun dijual di Indonesia. Selanjutnya biaya tenaga kerja lainnya berupa pemancangan, penanaman, pengendalian OPT, pemupukan dasar dengan jumlah biaya $\mathrm{Rp}$ 13.710.000. Secara keseluruhan, total biaya investasi usaha peremajaan karet ialah Rp 34.250.000,--

\section{4) Biaya Operasional TBM dan TM Karet}

Biaya operasional adalah biaya yang dikeluarkan didalam proyek peremajaan dan pemeliharaan karet setiap bulannya selama satu tahun. Biaya operasional usahatani karet ini dibagi menjadi biaya operasional tanaman belum menghasilkan (TBM) dengan biaya operasional tanaman menghasilkan (TM).
Biaya operasional tanaman belum menghasilkan pada tahun ke 1 sampai tahun ke 4, sedangkan tanaman untuk biaya operasional tanaman menghasilkan pada tahun ke 5 sampai tahun ke 25. Pada tahun ke 1 sampai 4 tenaga kerja yang digunakan adalah untuk kegiatan penyulaman dan pemiwilan, perbaikan piringan dan gawangan, pengendalian OPT, pemupukan dan penyiangan, berserta dengan pembelian bahan-bahan seperti pupuk, pestisida dengan total biaya Rp.33.819.000,-

Biaya operasional pada saat tanaman menghasilkan (TM) pada tahun ke 5 sampai tahun ke 25 memiliki biaya yang sama terdiri dari biaya tenaga kerja berupa pengendalian OPT, pemupukan dan penyiangan, dan beserta pembelian bahan- bahan seperti pupuk, pestida, yang berjumlah $\mathrm{Rp}$ 198.828.000 Pada usahatani ini tidak ada biaya pemanen dan pemeliharaan karena tenaga kerja yang dipakai adalah tenaga kerja dari keluarga itu sendiri.

Pada saat tanaman belum menghasilkan biaya yang dikeluarkan yaitu adalah biaya tenaga kerja, dalam biaya tenaga kerja terdiri dari kegiatan penyulaman, pemiwilan,

Tabel 9. Biaya Operasional TBM Karet Pada Tahun 1 - Tahun 4

\begin{tabular}{clr}
\hline \multicolumn{1}{c}{ Komponen } & \multicolumn{2}{c}{ Biaya (Rp) } \\
\hline No. & \multicolumn{2}{c}{7.980 .000} \\
2. & Tenaga Kerja & 25.839 .000 \\
\hline & Total dan Pestisida & .33 .819 .000 \\
\hline
\end{tabular}


Tabel 10. Biaya Operasional TM Karet Pada Tahun 5 - Tahun 25

\begin{tabular}{clr}
\hline No. Komponen & \multicolumn{2}{c}{ Biaya (Rp) } \\
\hline 1. & Tenaga Kerja & 32.760 .000 \\
2. & Pupuk & 141.120 .000 \\
3. & Pestisida & 8.568 .000 \\
4. & Sarana produksi & 16.380 .000 \\
\hline & Total & 198.828 .000 \\
\hline
\end{tabular}

pengendalian opt, dan penyiangan. Serta pembelian bahan sarana produksi berupa pupuk dan pestisida sebesar Rp 198.828.000.

\section{5) Produksi dan Penerimaan Usahatani Karet}

Usahatani karet pada lokasi penelitian mempunyai luas lahan sebesar 2 ha dengan

Tabel 11. Produksi dan Penerimaan Karet

\begin{tabular}{lrr}
\hline $\begin{array}{c}\text { Produksi } \\
\text { ke- }\end{array}$ & $\begin{array}{r}\text { Produksi }(\mathrm{lg} / \\
\text { tahun/kg) }\end{array}$ & $\begin{array}{l}\text { Penerimaan } \\
(\mathrm{Rp} / \mathrm{tahun} / \mathrm{lg})\end{array}$ \\
\hline 5 & 3.095 & 24.760 .800 \\
6 & 3.120 & 26.147 .405 \\
7 & 3.169 & 25.355 .059 \\
8 & 3.268 & 26.147 .405 \\
9 & 3.268 & 26.147 .405 \\
10 & 3.268 & 26.147 .405 \\
11 & 3.268 & 26.147 .405 \\
12 & 3.268 & 26.147 .405 \\
13 & 3.268 & 26.147 .405 \\
14 & 3.244 & 25.949 .318 \\
15 & 3.169 & 25.355 .059 \\
16 & 3.120 & 24.958 .886 \\
17 & 3.070 & 24.562 .714 \\
18 & 3.070 & 24.562 .714 \\
19 & 3.046 & 24.364 .627 \\
20 & 3.021 & 24.166 .541 \\
21 & 2.996 & 23.968 .454 \\
22 & 2.971 & 23.770 .368 \\
23 & 2.947 & 23.572 .282 \\
24 & 2.922 & 23.374 .195 \\
25 & 2.897 & 23.176 .109 \\
Total & 65.468 & 524.928 .960 \\
Rata-rata & 3.118 & 24.996 .617 \\
\hline & & \\
& &
\end{tabular}

jarak tanam yang sebesar $4 \times 3 \mathrm{~m}^{2}$ dengan jumlah tanaman 500 bibit, pembelian bibit sebanyak 550 buah dengan 50 bibit menjadi cadangan dalam melakukan penyulaman. Pada masa penanaman usahatani karet terbagi menjadi 2 fase yaitu tanaman belum menghasilkan (TBM) pada tahun 0 sampai tahun ke 4 dan fase selanjutnya tanaman menghasilkan dari tahun ke 4 sampai dengan tanaman tidak produktif lagi pada tahun ke 25.

Tanaman mulai bisa dilakukan pemanenan dan menghasilkan getah yang sudah bisa dimanfaatkan pada tahun ke 5, pada tahun ke 3 dan ke 4 pohon karet sudah menghasilkan getah yang belum kualitas yang bagus dan jumlah getahnya pun sedikit. Maka dari itu usahatani karet baru bisa dilakukan pemanenan pada tahun ke 5, dengan harga jual yang ditentukan oleh tengkulak dengan harga $\mathrm{Rp} 8000$ / kg. untuk hasil produksi dan penerimaan selama umur produktif dapat dilihat pada Tabel 11.

Dari hasil Tabel 11menunjukkan bahwa selama 25 tahun umur produktif tanaman karet dapat menghasilkan lateks sebanyak 65.468 Kg selama umur produktifnya dengan rata-rata produksi pertahunnya sebanyak $3.118 \mathrm{~kg}$, dan dengan total penerimaan sebesar Rp. 524.928.960 selama masa produktif tanaman, dengan rata-rata penerimaan setahun sebesar Rp 24.996.617,--

\section{6) Kriteria Kelayakan Usahatani Karet}

Analisis kelayakan finansial pada penelitian ini dari periode salama 25 tahun, dinilai berdasarkan umur ekonomis tanaman karet. Discount rate yang digunakan adalah 7 persen sesuai dengan tingkat suku bunga KUR pada Bank Pembangunan Sumatera 
Selatan dan Bangka Belitung. Usaha dikatakan layak untuk dijalankan apabila memiliki nilai NPV lebih dari 0 atau bernilai positif, nilai IRR yang lebih besar dari tingkat suku bunga yang digunakan, Net B/C Rasio yang lebih besar dari 1 dan Payback Period yang lebih kecil daripada periode usaha.

Berdasarkan hasil analisis kelayakan pada Tabel 12 usaha peremajaan karet dapat dikatakan layak secara finansial dengan kriteria sebagai berikut

\section{Net Present Value (NPV)}

NPV menurut Gray (2002) merupakan selisih antara Present Value (PV) arus benefit dengan Present Value (PV) arus biaya nilai sekarang. Dari hasil perhitungan untuk usahatani karet ini, NPV yang didapatkan adalah sebesar Rp 65.660.180 yang bersifat positif atau NPV $>0$, yang berarti usaha peremajaan karet memberikan manfaat positif sebesar Rp 65.660.180 selama umur usaha dijalankan (sampai 25 tahun). Sehingga dapat disimpulkan bahwa usaha peremajaan karet ini layak secara finansial untuk diusahakan karena akan memberikan keuntungan sebesar Rp.65.660.180,- selama umur produktif karet. Hasil penelitian Bardani, Ismail dan Kamarubayana (2014) juga menunjukangka NPV yang relatif sama jika menggunakan tingkat bunga $8 \%$ untuk 25 tahun umur usaha, yaitu sebesar Rp.64.991.408,- untuk NVP Analisa kelayakan karet.

\section{Internal Rate of Return (IRR)}

Internal Rate of Rasio (IRR) merupakan kriteria kelayakan yang memperlihatkan tingkat suku bunga yang akan membuat NPV $=$ bernilai sama dengan nol. Kriteria yang digunakan pada analisis ini menurut Peterson (2002) adalah IRR > OCC menggambarkan bahwa investasi yang akan dilakukan akan menghasilkan return lebih besar dari yang dirancang sebelumnya (layak untuk diusahakan), dan sebaliknya jika nilai IRR < OCC maka investasi yang dilakukan akan menghasilkan return lebih kecil dari yang ditargetkan (tidak layak untuk dilakukan), sedangkan IRR yang nilainya $=$ OCC menjadi pertimbangan bahwa investasi yang dilakukan diperkirakan menghasilkan return sebesar yang ditargetkan.

Hasil perhitungan IRR usaha peremajaan karet ini diperoleh nilai sebesar 7 persen. Nilai tersebut sama dengan tingkat suku bunga (OCC) yaitu 7 persen, maka bermakna usahatani karet ini jika dilakukan peremajaan pada kondisi sekarang hanya bisa bertahan atau menghasilkan keuntungan jika tingkat suku bunga berada pada angka 7 persen, artinya usaha ini masih layak untuk diusahakan, namun cenderung riskan apalagi jika dana yang digunakan berasal dari pinjaman, karena keuntungan yang diperoleh hanya sebesar nilai yang ditargetkan saja, jika terjadi kenaikan suku bunga yang bernilai lebih dari 7 persen, maka usahatani karet ini tidak layak lagi untuk dilanjutkan, atau tidak memiliki kemampuan lagi untuk dijalankan (jika dananya berasal dari pinjaman, maka petani tidak akan mampu lagi mengembalikan modal pinjamannya).

\section{Net $B / C$ Ratio}

Nilai Net B/C Rasio pada usaha peremajaan karet ini memiliki nilai sebesar 3,80 , yang artinya setiap pengeluaran biaya

Tabel 12. Hasil Kelayakan Finansial Pada Usaha Peremajaan Karet

\begin{tabular}{clrl}
\hline No & \multicolumn{1}{c}{ Kriteria Penilaian } & \multicolumn{1}{c}{ Hasil } & \multicolumn{1}{c}{ Keterangan } \\
\hline 1 & NPV & 65.660 .180 & Rupiah \\
2 & Net B/C & 3,80 & - \\
3 & Gross B/C & 1,46 & - \\
4 & IRR & $7 \%$ & Persen \\
5 & PBP & $10,2 / 122$ & Tahun/Bulan \\
6 & BEP Unit & 6,43 & Kilogram \\
7 & BEP Rupiah & 159.281 .036 & Rupiah \\
\hline
\end{tabular}


sebsar Rp.1.000,-, akan memeberikan benefit sebesar Rp.3.800,-. Artinya, dari kriteria B/C ratio usaha dikatakan layak karena nilainya Net $B / C$ Rasio $=1$. Semakin besar nilai Net $\mathrm{B} / \mathrm{C}$ Rasio tersebut, tentu saja akan menunjukkan bahwa usaha akan semakin menguntungkan (Pasaribu, 2012).

\section{Gross $B / C$}

Gross $B / C$ merupakan perbandingan antara Present Value Benefit dengan Present Value Cost. Apabila Cross B/C > 1, proyek layak untuk dilaksanakan sebaliknya Gross B/ $C<1$, proyek tidak layak untuk dilaksanakan. Perbedaannya dalam perhitungan Net $\mathrm{B} / \mathrm{C}$, biaya tiap tahun dikurangkan dari benefit tiap tahun untuk mengetahui benefit Rasio yang positif dan negatif. Sebaliknya, dalam perhitungan Gross $B / C$, pembilang adalah jumlah present value arus benefit dan penyebut adalah jumlah present value arus biaya. Semakin besar Gross $B / C$, semakin besar perbandingan antara benefit dengan biaya Artinya proyek relatif semakin layak. Sebaliknya, dalam perhitungan Gross $B / C$, pembilang adalah jumlah present value arus benefit (bruto) dan penyebut adalah jumlah present value arus biaya (bruto). Semakin besar Gross $B / C$, semakin besar perbandingan antara benefit dengan biaya. Artinya proyek relatif semakin layak.Nilai Gross $B / C$ pada usaha peremajaan karet bernilai 1,46. Usaha dikatakan layak karena memiliki nilai Gross $B / C$ Rasio lebih dari satu. Semakin besar nilai yang diperoleh tersebut, maka usaha ini layak untuk dilakukan.

\section{Payback Period (PBP)}

Payback Period menunjukan kemampuan tingkat pengembalian usaha atau modal pada suatu usaha atau proyek. Suatu usaha dapat dikatakan layak apabila memiliki nilai payback period yang lebih kecil dari umur proyek. Payback period usaha peremajaan karet adalah 10,2 tahun atau 122 bulan. Umur usaha peremajaan karet ini adalah adalah 25 tahun maka dapat dikatakan payback period dalam usaha peremajaan kelapa sawit ini masih didalam umur usaha, dan dapat dinyatakan bahwa usaha layak untuk dijalankan.

\section{Break Event point Unit (BEP Unit)}

BEP yang dinyatakan dalam jumlah penjualan produk dinilai tertentu. Berdasarkan perhitungan dari analisis usaha peremajaan karet bernilai 5,87. Artinya adalah jika ingin mencapai BEP unit maka harus melakukan penjualan setiap pemanenan sebanyak 6,43 kilogram / panen.

\section{Break Event Point Rupiah}

BEP yang dinyatakan dalam jumlah penjualan dinilai tertentu. Berdasarkan perhitungan dari analisis usaha peremajaan karet bernilai $\mathrm{Rp}$ 159.281.036. artinya adalah jika ingin mencapai BEP rupiah maka harus mendapatkan keuntungan dari penjualan produk sebesar Rp 142.144.730

Pada penelitian Azizah, Wijana dan Effendi (2015) menunjukkan bahwa, mayoritas usahatani karet di Sumatera Selatan masih berada dalam kondisi layak untuk diusahakan, namun tingkat kelayakan akan semakin baik, jika di tingkat kelompok dilanjutkan dengan usaha di sektor hilirnya. Rekomendasi ini baik untuk dilakukan pada petani di wilayah kajian mengingat harga pada produk mentah ini cenderung kurang stabil.

\section{Analisis Sensitivitas}

Analisis sensitivitas dilakukan untuk mengetahui kepekaan suatu usaha atau proyek terhadap sekenario atau perubahan-perubahan yang akan terjadi. Analisis sensitivitas yang dilakukan pada penelitian ini menggunakan switching value pada sekenario kenaikan harga bahan baku dan penurunan produksi pada tanaman perkebunan karet. Analisis ini merupakan perhitungan untuk mengukur tingkat sensitivitas atau kepekaan suatu usaha apabila keadaan diubah. Analisis dilakukan sampai memperoleh NPV mendekati angka nol, IRR sama dengan suku bunga sebesar 7 Persen dan Net B/C Rasio mendekati angka satu.

Pertimbangan penggunan nilai pengaruh pada penurunan harga slab didasarkan bahwa hal tersebut merupakan hal yang penting dan berpengaruh pada perubahan biaya maupun penerimaan, dalam besaran sensitivitas ini 
Tabel 13. Hasil Sensitivitas Penurunan Harga Produk Karet

\begin{tabular}{clr}
\hline No. & \multicolumn{1}{c}{ Kriteria Penilaian } & Karet \\
\hline 1. & NPV & 55.199 .162 \\
2. & Net B/C & 3,49 \\
3. & Gross B/C & 1,38 \\
4. & IRR & $6,07 \%$ \\
5. & PBP & 10,6 Tahun/ 127 Bulan \\
6. & BEP Unit & 8,39 \\
7. & BEP Rupiah & 197.387 .939 \\
\hline
\end{tabular}

diasumsikan mengalami penurunan harga sebesar 5\% untuk hasil sensitivitas terhadap penurunan harga produksi dapat dilihat pada Tabel 13.

Dari hasil analisis diatas bahwa pada usaha peremajaan karet sensitif terhadap penurunan harga dari produk karet. Untuk usaha peremajaan karet dengan penurunan harga produk sebesar 5 persen usaha tersebut mengalami penurunan yang cukup banyak dilihat IRR mencapai nilai 6,07 persen dibawah tingkat suku bunga sebesar 7 persen, bahwa dapat dinyatakan usaha tersebut tidak bisa bertahan dengan penurunan harga sebesar 5 persen.

\section{SIMPULAN DAN SARAN}

Sistem budidaya karet yang diterapkan oleh masyarakat dalam menjaga produktifitas tanaman karetnya masih mengikuti cara-cara konvensional yang telah dilakukan secara turun menurun, minim sentuhan teknologi dan inovasi, sehingga banyak bagian proses yang tidak berpedoman pada Good Agricultural Practices yang menjadi penyebab produktifitas dan mutu karet masih tergolong rendah. Usaha replanting karet yang akan dilakukan petani, dalam pengusahaannya nanti menunjukkan masih berada pada kriteria layak, dimana hasil perhitungan pada bagian-bagian kriteria kelayakan menunjukkan nilai NPV pada Df 7\% dengan nilai Rp 65.660.180, IRR 7,00\%, Net B/C 3.80, Gross B/C 1.46, PBP 10,2 tahun, BEP Unit 6,43, dan BEP Rupiah Rp 159.281.036dan hasil sensitivitas kelayakan finansial karet ditandai dengan nilai NPV Rp
55.199.182, IRR 6,07\%, Net B/C 3.49, Gross B/C 1.38, PBP 10,6 tahun, BEP Unit 8,39, dan BEP Rupiah Rp 197.387.939, dan kesemuanya menujukkan usaha ini masih layak untuk diusahakan. Dari aspek kelayakan non finansial juga menunjukkan kecenderungan layak pada aspek teknis, pemasaran, dan manajemen.

\section{DAFTAR PUSTAKA}

Anwar, R.N dan Suwarto. 2016. Pengelolaan tanaman karet (Heveabrasiliensis muell.arg) di sumatera utara dengan aspek khusus pembibitan. Buletin Agrohorti 4(1). Departemen Agronomi dan Hortikultura, Fakultas Pertanian, Institut Pertanian Bogor

Azizah F.A., S.Wijana dan M. Effendi. 2015. Analisis kelayakan teknis dan finansial pada industri pengolahan karet skala kecil Di Kabupaten Musi Rawas Sumatera Selatan. Jurnal Industria 4(1): $53-65$.

BPS. 2018. Sumatera Selatan Dalam Angka. Badan Pusat Statistik

Balai Penelitian Sembawa. 2010. Usahatani Budidaya Tanaman Karet.

BSN. 2010. Standarisasi Indonesian Rubber. Badan Standarisasi Nasional

Bardani, Z, Ismail dan L. Kamarubayana. 2014. Studi kelayakan usahatani karet di Desa Bunga Putih Kecamatan 
Marangkayu Kabupaten Mutai

Kartanegara. Jurnal Agrifor 13(2)

Dinas Perkebunan. 2017. Statistik 2016. Kantor Dinas Perkebunan Provinsi Sumatera Selatan. Sumatera Selatan

Fahrurrozi. 2015. Analisis efisiensi saluran pemasaran bahan olahan karet rakyat (BOKAR) lump mangkok dari Desa Kompas Raya Kecamatan Pinoh Utara Kabupaten Melawi. Jurnal AGRISE ( Diakses tanggal 7 November 2018 ).

Gray, C. 2002. Pengantar Evaluasi Proyek. Jakarta. Gramedia

Pasaribu,A.M. 2012. Perencanaan dan Evaluasi Proyek Agribisnis: Konsep dan Aplikasi. Yogyakarta. Lily Publisher.

Pusat Penelitian Karet. 2003. Sapta Bina Usahatani Karet Rakyat. Balai Penelitian Sembawa. Palembang

Putra, Syawaludin Sah. 2015. Kajian biaya replanting tanaman karet (Hevea brasiliensis) di Afdeling I Kebun Gergas PT.GERGAS UTAMA. Sekolah Tinggi Ilmu Pertanian. Agrobisnis Perkebunan. Medan.

Raden. 2014. Analisis komparasi pendapatan usahatani karet petani yang menjual kepasar lelang dan luar pasar lelang di Kecamatan Sekernan Kabupaten Muaro Jambi. Jurnal Sosio Ekonomika Bisnis 17(2). (Diakses tanggal 27 September 2017).

Samisara, F. 2011. Potensi tanaman karet (Hevea brasiliensis) sebagai komoditi agribisnis.

http://hutanb2011.co.id/2013/06/poten si-tanaman-karet-hevea.html. (Diakses tanggal 25 Oktober 2017)

Stiawan, A. 2014. Faktor-faktor yang mempengaruhi pendapatan petani karet di Desa Getas Kecamatan Singorojo Kabupaten Kendal. Jurnal MEDIAGRO 10(2): 69-80. (Diakses tanggal 30 September 2017).

Syarifah. 2014. Studi kelayakan investasi pembangunan perkebunan karet di Sumatera Selatan. Jurnal Penelitian Karet 32(2). Retrieved from http://ejournal.puslitkaret.co.id/index.p $\mathrm{hp} / \mathrm{jpk} /$ article/view/161 